\title{
STUDY OF ANTIDIABETIC ACTIVITY OF HIPTAGE BENGHALENSIS (L) KURZ
}

\author{
J. JANORIOUS WINKA*, V.MAITHILI, J.JAYAPRAKASH \\ NARAYANAN, M. RAJKUMAR \& K.L. SENTHIL KUMAR \\ Departments of Pharmacognosy, Padmavathi College of Pharmacy \& Research Institute, Periyanahalli, \\ Dharmapuri - 635205, Tamil Nadu, India.
}

\begin{abstract}
Objective: To evaluate the antidiabetic activity of ethanolic extract of Hiptage benghalensis (l) kurz in Streptoz ot oc in induced diabetic rats.

Materials and Methods: The authenticated stem of Hiptage benghalensis $(H B)$ were collected from ABS botanical garden, Salem, Tamil Nadu. The ethanol extract was tested for acute oral toxicity study by using OECD guidelines 423 . The starting dose level of Ethanolic extract of $H B$ was $2000 \mathrm{mg} / \mathrm{kg}$. Body weight p.o. and the route of administration was oral. Dose volume was administered $0.1 \mathrm{ml} / 100$ gms body weight to the rats, which were fasted over night with water ad libitum. Assessment of antidiabetic activity was carried out on albino wistar rats. The animals were segregated into five groups of six animals each.

Acute toxicity study revealed the non-toxic nature of the Hiptage benghalensis extract. There was no mortality or any toxic reactions found at the maximum tested dose level of $2000 \mathrm{mg} / \mathrm{kg}$. The serum glucose levels of normal rats reached a peak at $60 \mathrm{~min}$ after the oral administration of glucose $(3 \mathrm{~g} / \mathrm{kg}$ ) and gradually decreased to $116.0 \mathrm{mg} / \mathrm{dl} \mathrm{and} 104.2$ $\mathrm{mg} / \mathrm{dl}$ in 2 hours. The pretreatment with Hiptage bengahlensis extract (100 and $200 \mathrm{mg} / \mathrm{kg}$ ) and Glebinclamide (2.5 $\mathrm{mg} / \mathrm{kg}$ ) elicited decreased serum glucose level significantly $(\mathrm{p}<0.001)$ as compared to the control group. On repeated oral administration of the vehicle, Hiptage benghalensis extract or Glebinclamide, for 21 days, a sustained and significant ( $\mathrm{p}<$ 0.001) decrease in the serum blood glucose of the diabetic rats was observed at a dose of 100 and $200 \mathrm{mg} / \mathrm{kg}$ in a dose dependent manner as compared to the vehicle treated group. Glebinclamide also showed a significant $(p<0.001)$ decrease in serum glucose at a dose of $2.5 \mathrm{mg} / \mathrm{kg}$, p.o. as compared with the vehicle treated group. The results of the present study indicate that Hiptage benghalensis extract (100 and $200 \mathrm{mg} / \mathrm{kg}$ b.w.) was found to reduce the glucose level in glucose loaded animals and in STZ induced diabetic animals.

STZ has been shown to induce free radical production and cause tissue injury. The pancreas is especially susceptible to the action of STZ-induced free- radical damage (Hunt, 1990). Induction of diabetes with STZ is associated with a characteristic loss of body weight, which is due to increased muscle wasting and due to loss of tissue proteins. In STZ animals, there was an increase in the value of total cholesterol (TCH), triglycerides (TG), LDL, VLDL, except HDL and protein values (albumin and total protein), while the extract treated group showed an increased value of HDL, protein values, and reduced VLDL, TC, and TG in a significant manner. This reduced the VLDL, TC, and TG; it may be presumed that the extract is responsible for the enhancement of the transcription of lipoprotein lipase similar to that of insulin, since in the untreated or under treated diabetes animals, the level of triglycerides and cholesterol increases due to increased production of VLDL and unavailability of protein lipase which hydrolyses the triglycerides to VLDL because of insulin deficiency.
\end{abstract}

Results: The acute oral toxicity studies showed that ethanolic extract of HB up to $2000 \mathrm{mg} / \mathrm{kg}$ are non toxic and safe. This study shows that ethanolic extract of $B H$ possess significant antidiabetic activity. This antidiabetic activity shown by the $H B$ may be possibly due to the active constituent present in the extract which is responsible for the pharmacological action.

Conclusion: The results indicates that ethanolic extract of HB stem possesses significant antidiabetic activity.

Key words: Antidiabetic activity, Streptozotocin, Hiptage benghalensisi (l) kurz and Acute oral toxicity study.

\section{Introduction}

In recent years there has been a tremendous increase in demand for herbal drugs due to its safety, efficacy and better therapeutic results. Due to its economic pricing as compared to synthetic or allopathic drugs, which have several therapeutic complications, herbal drugs are more preferred nowadays. Developing of drug as antidiabetic agent involves screening of large number of phytochemical and natural products for their specific and non-specific antidiabetic activity against many types of chemical agents. There are many natural products which are used as potential anti diabetic agents. Looking at the scope of herbal drug and increasing demand of my plant especially in diabetic, hepatoprotective, AIDS, skin diseases, stomatitis and cancer etc. 
Materials and Methods: Animals: Healthy Wistar rats of either sex, weighing 180-220 gms were procured from the animal house. The animal house was well ventilated and animals had about 12 hour day and night schedule. The animals were housed in cages during the course of the experimental period and the room temperature was maintained. The animals were fed with standard rat feed and water. The experiments were conducted as per the approved protocol.

Preparation of drug solution: The extract of Hiptage benghalensis and standard Glebinclamide were dissolved in $0.9 \%$ sodium chloride in water and administered orally to the animals with the help of an intra-gastric catheter.

Acute oral toxicity study: Acute oral toxicity test was carried out in Wistar albino rats of either sex (180-220 gms, b.w.) were used. Rats were kept for overnight fasting prior to drug administration. A total of three animals were used, which received a single oral dose (2000 $\mathrm{mg} / \mathrm{kg}$, b.w.) of Hiptage benghalensis extract. After the administration of extract, food was withheld for further 3-4 hours. Animals were observed individually at least once during the first 30 min after dosing, periodically during the first 24 hours (with special attention during the first 4 hours), and daily thereafter for a period of 14 days. Once daily, cage side observations included changes in skin and fur, eyes and mucous membrane (nasal) and also respiratory rate, circulatory (heart rate and blood pressure), autonomic (salivation, lacrimation, perspiration, piloerection, urinary incontinence, and defecation) and central nervous system (drowsiness, gait, tremors, and convulsion) changes. Mortality, if any, was determined over a period of 2 weeks.

Oral Glucose Tolerance Test (OGTT): The oral glucose tolerance test was performed in overnight fasted (18 hours) normal rats. Rats were divided into four groups, each consisting of six rats were administered $0.9 \% \mathrm{w} / \mathrm{v}$ saline, Glebinclamide $2.5 \mathrm{mg} / \mathrm{kg}$, and Hiptage benghalensis extract (100 and $200 \mathrm{mg} / \mathrm{kg}$ ), respectively. Glucose (3 g/ $\mathrm{kg})$ was fed 30 min after the administration of extract. Blood was withdrawn from the retro orbital sinus under ether inhalation at 0 , 30, 60 , and $120 \mathrm{~min}$ of glucose administration and blood glucose level was estimated by glucose oxidase-peroxidase method.

Experimental design: Overnight fasted diabetic rats were divided into four groups of six animals in each group. Group I animals served as normal control, which received $0.9 \%$ sodium chloride and group II served as diabetic control. Group III and IV, diabetic rats were treated with extract of Hiptage benghalensis (100 and $200 \mathrm{mg} / \mathrm{kg} \mathrm{b.w.,} \mathrm{p.o.).} \mathrm{Group} \mathrm{V,} \mathrm{which}$ served as positive control, was treated with Glebinclamide $2.5 \mathrm{mg} / \mathrm{kg}$ b.w., p.o. All the treatments were carried out for a period of 21 days. Body weight of the animals was recorded every week. The fasting blood samples were collected on days $1,7,14$, and 21 to determine the glucose level by glucose oxidase and peroxidase method. At the end of the treatments, the blood samples were collected by retro orbital puncture and serum was separated by centrifugation at 4000 rpm for $15 \mathrm{~min}$. The separated serum was used for biochemical estimation. Triglycerides, total cholesterol, total protein, albumin, creatinine, and HDL- cholesterol were analyzed from the serum by auto analyzer. VLDL (very low density lipoprotein)- cholesterol was calculated as: triglycerides/5; LDL (low density lipoprotein)-cholesterol was calculated by the equation: LDL-cholesterol = total cholesterol-(HDL+VLDL) The animals were sacrificed by cervical dislocation under mild ether anesthesia and the pancreas was excised immediately for histopathological studies. 
Table No 1: Data of Acute Toxicity Class Method for Hiptage benghalensis (L) Kurz

\begin{tabular}{|c|c|c|c|c|c|c|c|c|}
\hline \multirow{2}{*}{ S.No } & \multirow{2}{*}{ Group } & \multirow{2}{*}{ Dose } & \multicolumn{2}{|c|}{$\begin{array}{l}\text { Weight of animal } \\
\text { in gms }\end{array}$} & \multirow{2}{*}{$\begin{array}{l}\text { Signs of } \\
\text { toxicity }\end{array}$} & \multirow{2}{*}{$\begin{array}{l}\text { Onset of } \\
\text { toxicity }\end{array}$} & \multirow{2}{*}{$\begin{array}{l}\text { Reversible / } \\
\text { Irreversible }\end{array}$} & \multirow{2}{*}{$\begin{array}{l}\text { Duration of } \\
\text { observation }\end{array}$} \\
\hline & & & $\begin{array}{l}\text { Befor } \\
\text { e Test }\end{array}$ & $\begin{array}{l}\text { After test } \\
\text { on } 4^{\text {th }} \text { day }\end{array}$ & & & & \\
\hline 1 & $\begin{array}{c}\text { Ethanolic } \\
\text { extract }\end{array}$ & $\begin{array}{c}2 \mathrm{~g} / \\
\mathrm{kg}\end{array}$ & 172 & 170 & $\begin{array}{l}\text { No signs } \\
\text { of toxicity }\end{array}$ & Nil & Nil & 14 Days \\
\hline 2 & $\begin{array}{c}\text { Ethanolic } \\
\text { extract }\end{array}$ & $\begin{array}{c}2 \mathrm{~g} / \\
\mathrm{kg}\end{array}$ & 165 & 163 & $\begin{array}{l}\text { No signs } \\
\text { of toxicity }\end{array}$ & Nil & Nil & 14 Days \\
\hline 3 & $\begin{array}{c}\text { Ethanolic } \\
\text { extract }\end{array}$ & $\begin{array}{c}2 \mathrm{~g} / \\
\mathrm{kg}\end{array}$ & 155 & 150 & $\begin{array}{l}\text { No signs } \\
\text { of toxicity }\end{array}$ & Nil & Nil & 14 Days \\
\hline & \multicolumn{8}{|c|}{ As no toxicity or death was observed for these dose levels, the same dose level was tried again } \\
\hline 4 & $\begin{array}{c}\text { Ethanolic } \\
\text { extract }\end{array}$ & $\begin{array}{c}2 \mathrm{~g} / \\
\mathrm{kg}\end{array}$ & 170 & 168 & $\begin{array}{l}\text { No signs } \\
\text { of toxicity }\end{array}$ & Nil & Nil & 14 Days \\
\hline 5 & $\begin{array}{c}\text { Ethanolic } \\
\text { extract }\end{array}$ & $\begin{array}{c}2 \mathrm{~g} / \\
\mathrm{kg}\end{array}$ & 163 & 161 & $\begin{array}{l}\text { No signs } \\
\text { of toxicity }\end{array}$ & Nil & Nil & 14 Days \\
\hline 6 & $\begin{array}{c}\text { Ethanolic } \\
\text { extract }\end{array}$ & $\begin{array}{l}2 \mathrm{~g} / \\
\mathrm{kg}\end{array}$ & 170 & 168 & $\begin{array}{l}\text { No signs } \\
\text { of toxicity }\end{array}$ & Nil & Nil & 14 Days \\
\hline
\end{tabular}

\section{Oral Glucose Tolerance Test (OGTT)}

Table No. 2: Effect of Hiptage benghalensis extract in fasted normal rats by OGTT

\begin{tabular}{|l|l|l|l|l|}
\hline \multirow{2}{*}{\multicolumn{1}{|c|}{ Oral Glucose Tolerance Test }} \\
\hline \multirow{2}{*}{ Treatment } & \multicolumn{3}{|c|}{ Blood Glucose Level (mg/dl) } \\
\cline { 2 - 5 } & $\mathbf{0}$ min & \multicolumn{1}{|c|}{$\mathbf{3 0}$ min } & \multicolumn{1}{c|}{$\mathbf{6 0}$ min } & 120 min \\
\hline Normal control & $83.8 \pm 2.60$ & $140.2 \pm 5.3$ & $183.4 \pm 5.76$ & $124.6 \pm 3.17$ \\
\hline $\begin{array}{l}\text { Glebinclamide } \\
(2.5 \mathrm{mg} / \mathrm{kg})\end{array}$ & $\begin{array}{l}91.0 \pm \\
2.20^{\mathrm{a}}\end{array}$ & $103.0 \pm 3.60^{\mathrm{a}}$ & $105.4 \pm 2.33^{\mathrm{a}}$ & $96.2 \pm 3.17^{\mathrm{a}}$ \\
\hline $\begin{array}{l}\text { Hiptage benghalensis }(100 \mathrm{mg} / \\
\mathrm{kg})\end{array}$ & $82.8 \pm 2.5$ & $128.0 \pm 5.45^{\mathrm{b}}$ & $128.8 \pm 3.59^{\mathrm{a}}$ & $116.0 \pm 5.8$ \\
\hline $\begin{array}{l}\text { Hiptage benghalensis }(200 \mathrm{mg} / \\
\mathrm{kg})\end{array}$ & $87.2 \pm 4.20$ & $110.8 \pm 3.77^{\mathrm{b}}$ & $114.2 \pm 4.62^{\mathrm{a}}$ & $104.2 \pm 1.77^{\mathrm{b}}$ \\
\hline
\end{tabular}

The results are expressed as mean \pm S.E.M. $(n=6){ }^{a} \mathrm{p}<0.001,{ }^{b} \mathrm{p}>0.01$ and ${ }^{c} \mathrm{p}<0.05$ extract / drug treated groups were compared with control group. One way ANOVA by Tukey's multiple comparison test. 
Graph No. 1: Effect of Hiptage benghalensis extract in fasted normal rats by OGTT

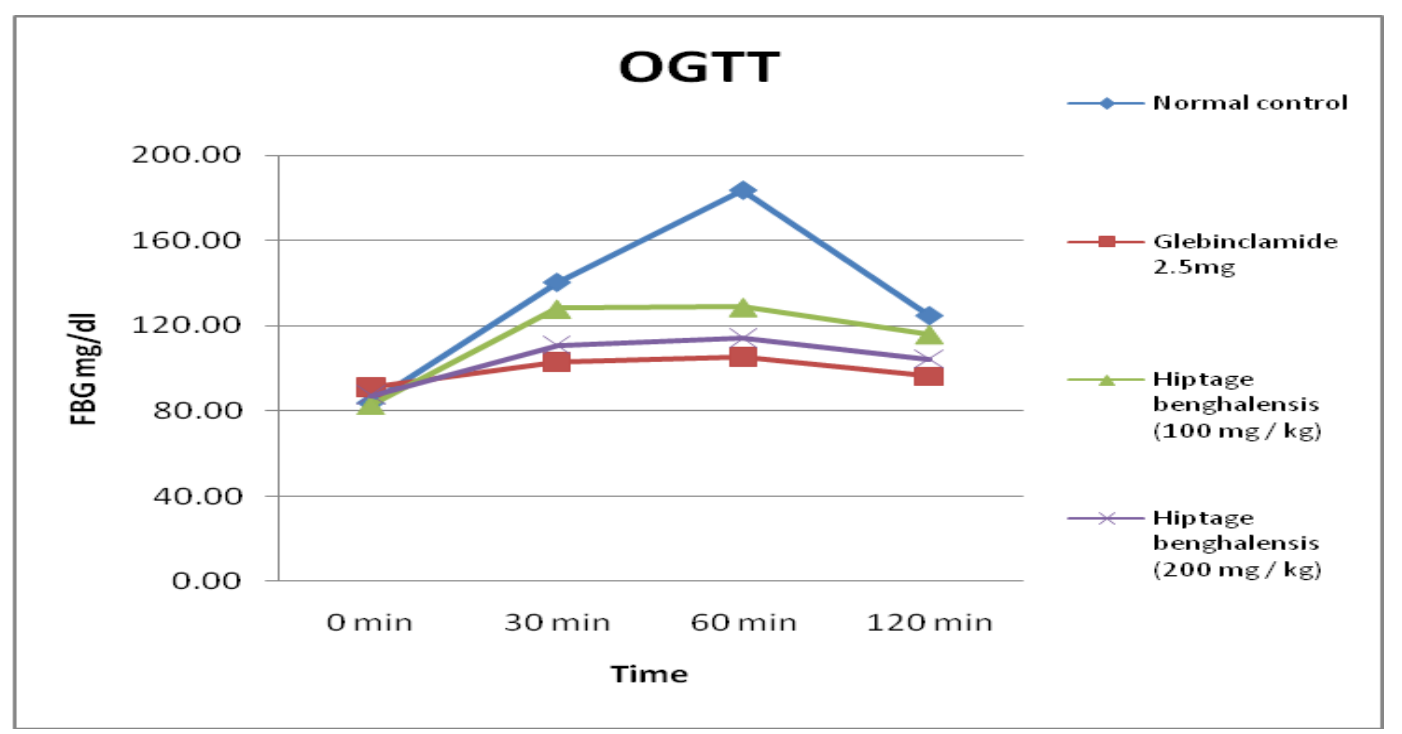

Table No. 3: Effect of Hiptage benghalensis extract on Serum Blood Glucose Level of STZ - induced diabetic rats

\begin{tabular}{|l|c|c|c|c|}
\hline \multirow{2}{*}{ Treatment } & \multicolumn{3}{|c|}{ Blood Glucose Level (mg/dl) } \\
\cline { 2 - 5 } & 0 day & 7 days & 14 days & 21 days \\
\hline $\begin{array}{l}\text { Normal } \\
(1 \mathrm{ml} / \mathrm{kg}, \mathrm{p.o.})\end{array}$ & $98.80 \pm 4.35$ & $94.2 \pm 2.87$ & $98.6 \pm 4.00$ & $94.0 \pm 2.60$ \\
\hline Diabetic control & $269.4 \pm 5.32$ & $318.2 \pm 12.11^{\mathrm{a}}$ & $338.6 \pm 12.59^{\mathrm{a}}$ & $362.2 \pm 6.71^{\mathrm{a}}$ \\
\hline $\begin{array}{l}\text { STZ }+ \text { Glebinclamide }(2.5 \\
\text { mg/kg) }\end{array}$ & $266.0 \pm 6.99$ & $173.0 \pm 5.2^{\mathrm{a}}$ & $134.0 \pm 4.28^{\mathrm{a}}$ & $116.4 \pm 3.44^{\mathrm{a}}$ \\
\hline $\begin{array}{l}\text { Hiptage benghalensis } \\
(100 \mathrm{mg} / \mathrm{kg})\end{array}$ & $282.0 \pm 7.47$ & $225.8 \pm 8.39^{\mathrm{a}}$ & $176.2 \pm 5.08^{\mathrm{a}}$ & $139.8 \pm 0.96^{\mathrm{a}}$ \\
\hline $\begin{array}{l}\text { Hiptage benghalensis } \\
(200 \mathrm{mg} / \mathrm{kg})\end{array}$ & $269.6 \pm 10.98$ & $163.8 \pm 8.65^{\mathrm{a}}$ & $147.8 \pm 5.17^{\mathrm{a}}$ & $127.0 \pm 3.03^{\mathrm{a}}$ \\
\hline
\end{tabular}

The results are expressed as mean \pm S.E.M. $(n=6){ }^{a} \mathrm{p}<0.001,{ }^{b} \mathrm{p}>0.01$ and ${ }^{c} \mathrm{p}<0.05$ extract / drug treated groups were compared with control group. $\mathrm{p}<0.001$ diabetic control group was compared with normal group. One way ANOVA by Tukey's multiple comparison test. 
Graph No. 2: Effect of Hiptage benghalensis extract on Serum Blood Glucose Level of STZ - induced diabetic rats

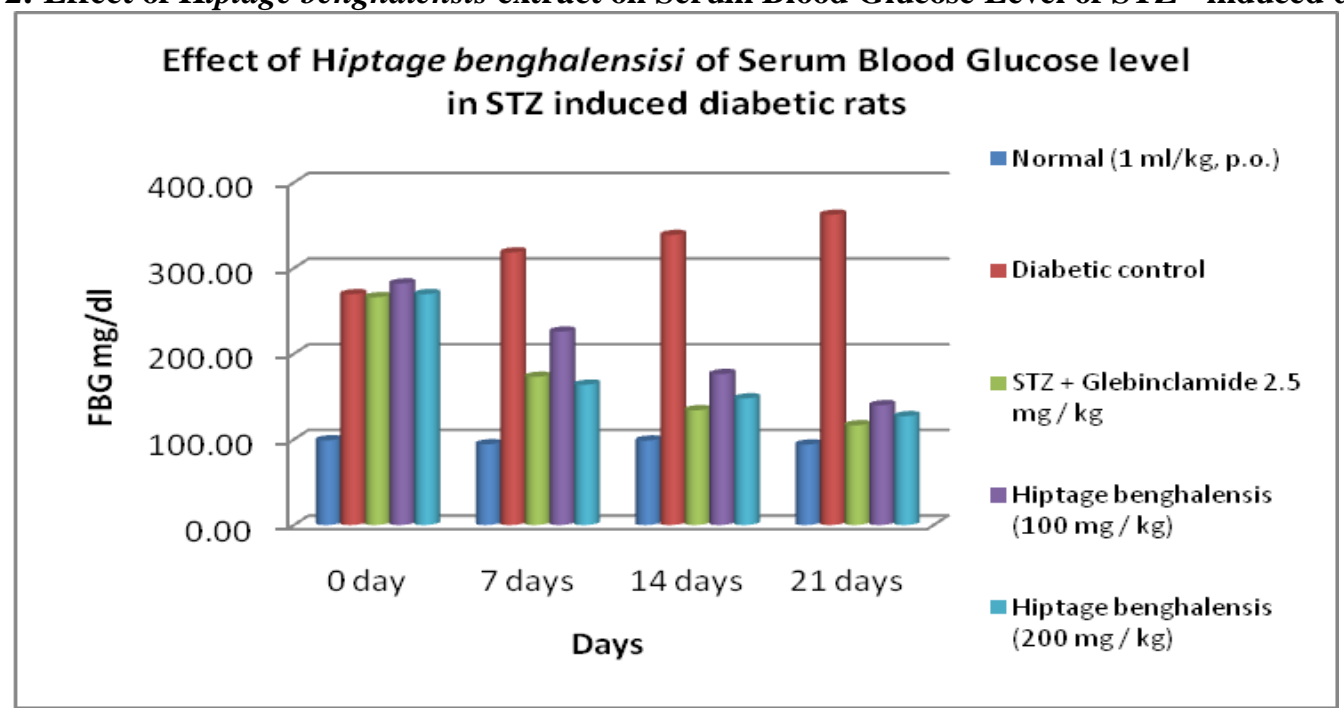

Table No. 4: Effect of Hiptage benghalensis extract on body weight in STZ - induced diabetic rats

\begin{tabular}{|c|c|c|c|c|}
\hline \multirow{2}{*}{ Treatment } & \multicolumn{3}{|c|}{ Body Weight (gm) } \\
\cline { 2 - 5 } & 0 day & 7 days & 14 days & 21 days \\
\hline $\begin{array}{c}\text { Normal (1 ml/kg, p.o.) } \\
\text { (205.2 } \pm 5.91\end{array}$ & $212.2 \pm 5.60$ & $219.8 \pm 5.86$ & $225.2 \pm 5.45$ \\
\hline $\begin{array}{c}\text { Diabetic control } \\
\text { (2.5 mg / kg) }\end{array}$ & $199.0 \pm 5.20$ & $176.4 \pm 2.29^{\mathrm{a}}$ & $164.2 \pm 4.37^{\mathrm{a}}$ & $159.0 \pm 2.74^{\mathrm{a}}$ \\
\hline $\begin{array}{c}\text { STZ + Glebinclamide } \\
\text { Hiptage benghalensis (100 }\end{array}$ & $198.8 \pm 3.54$ & $202.0 \pm 4.81^{\mathrm{b}}$ & $200.2 \pm 6.99^{\mathrm{a}}$ & $208.2 \pm 4.39^{\mathrm{a}}$ \\
\hline $\begin{array}{c}\text { Hiptage benghalensis }(200 \\
\text { mg/kg, p.o. })\end{array}$ & $204.0 \pm 3.94$ & $197.0 \pm 3.00^{\mathrm{c}}$ & $195.2 \pm 4.18^{\mathrm{b}}$ & $204.4 \pm 3.41^{\mathrm{a}}$ \\
\hline
\end{tabular}

The results are expressed as mean \pm S.E.M. $(n=6){ }^{\mathrm{a}} \mathrm{p}<0.001,{ }^{\mathrm{b}} \mathrm{p}>0.01$ and ${ }^{c} \mathrm{p}<0.05$ extract / drug treated groups were compared with control group. $\mathrm{p}<0.001$ diabetic control group was compared with normal group. One way ANOVA by Tukey's multiple comparison test. 
Graph No. 3: Graph showing effect of Hiptage benghalensis extract on body weight in STZ - induced diabetic rats

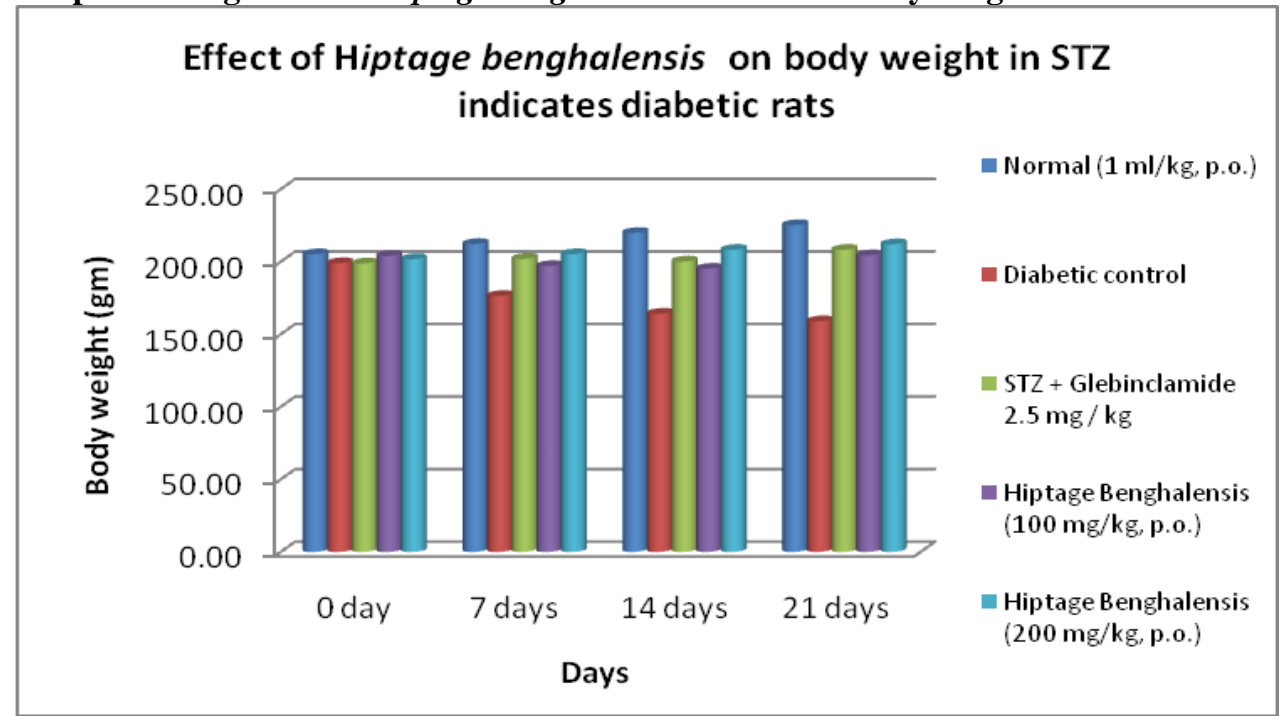

Table No. 5: Effect of extract of Hiptage benghalensis on Serum Lipid profile, Serum Albumin, Total protein, and Creatinine in STZ induced diabetic rats

\begin{tabular}{|c|c|c|c|c|c|c|c|c|}
\hline Groups & $\begin{array}{c}\mathrm{TCH} \\
(\mathrm{mg} / \mathrm{dl})\end{array}$ & $\begin{array}{c}\text { TG } \\
(\mathrm{mg} / \mathrm{dl})\end{array}$ & $\begin{array}{c}\text { HDL } \\
(\mathrm{mg} / \mathrm{dl})\end{array}$ & $\begin{array}{c}\text { LDL } \\
(\mathrm{mg} / \mathrm{dl})\end{array}$ & $\begin{array}{c}\text { VLDL } \\
(\mathrm{mg} / \mathrm{dl})\end{array}$ & $\begin{array}{c}\mathrm{TP} \\
(\mathrm{g} / \mathrm{dl})\end{array}$ & $\begin{array}{l}\text { Albumin } \\
(\mathrm{g} / \mathrm{dl})\end{array}$ & $\begin{array}{c}\text { CR } \\
(\mathrm{mg} / \mathrm{dl})\end{array}$ \\
\hline $\begin{array}{l}\text { Normal (1 } \\
\text { ml/kg, p.o.) }\end{array}$ & $\begin{array}{c}120.11 \pm \\
3.52\end{array}$ & $\begin{array}{c}80.31 \pm \\
4.03\end{array}$ & $\begin{array}{c}55.21 \pm \\
1.65\end{array}$ & $\begin{array}{c}46.81 \pm \\
3.10\end{array}$ & $\begin{array}{c}14.12 \pm \\
0.80\end{array}$ & $\begin{array}{c}6.1 \pm \\
0.20\end{array}$ & $\begin{array}{l}5.9 \pm \\
0.24\end{array}$ & $\begin{array}{c}0.51 \pm \\
0.20\end{array}$ \\
\hline Diabetic control & $\begin{array}{c}270.1 \pm \\
7.30 \mathrm{a}\end{array}$ & $\begin{array}{c}181.13 \pm \\
4.30 \mathrm{a}\end{array}$ & $\begin{array}{c}26.16 \pm \\
1.28 \mathrm{a}\end{array}$ & $\begin{array}{c}208.42 \pm \\
8.47 \mathrm{a}\end{array}$ & $\begin{array}{c}35.92 \pm \\
0.85 \mathrm{a}\end{array}$ & $\begin{array}{l}3.21 \pm \\
0.20 \mathrm{a}\end{array}$ & $\begin{array}{l}3.2 \pm \\
0.11 \mathrm{a}\end{array}$ & $\begin{array}{c}1.8 \pm \\
0.06 \mathrm{a}\end{array}$ \\
\hline $\begin{array}{l}\text { STZ + } \\
\text { Glebinclamide } \\
2.5 \mathrm{mg} / \mathrm{kg}\end{array}$ & $\begin{array}{c}130.67 \pm \\
2.80^{b}\end{array}$ & $\begin{array}{c}100.1 \pm \\
5.80 \mathrm{~b}\end{array}$ & $\begin{array}{c}57.17 \pm \\
2.44 b\end{array}$ & $\begin{array}{c}55.41 \pm \\
2.96 \mathrm{~b}\end{array}$ & $\begin{array}{l}19.09 \pm \\
1.16^{b}\end{array}$ & $\begin{array}{l}5.98 \pm \\
0.17 \mathrm{~b}\end{array}$ & $\begin{array}{l}5.51 \pm \\
0.17 \mathrm{~b}\end{array}$ & $\begin{array}{l}0.58 \pm \\
0.06 \mathrm{~b}\end{array}$ \\
\hline $\begin{array}{l}\text { STZ + Hiptage } \\
\text { benghalensis } \\
(100 \mathrm{mg} / \mathrm{kg}, \\
\text { p.o. })\end{array}$ & $\begin{array}{c}150.15 \pm \\
5.34 \mathrm{~b}\end{array}$ & $\begin{array}{c}138.56 \pm \\
4.30 \mathrm{~b}\end{array}$ & $\begin{array}{l}44.78 \pm \\
1.50 \mathrm{~b}\end{array}$ & $\begin{array}{l}78.84 \pm \\
7.67 \mathrm{~b}\end{array}$ & $\begin{array}{c}26.55 \pm \\
0.84 \mathrm{~b}\end{array}$ & $\begin{array}{l}5.00 \pm \\
0.20^{c}\end{array}$ & $\begin{array}{l}4.78 \pm \\
0.20 b\end{array}$ & $\begin{array}{l}0.76 \pm \\
0.04 \mathrm{~b}\end{array}$ \\
\hline $\begin{array}{l}\text { STZ + Hiptage } \\
\text { benghalensis } \\
(200 \mathrm{mg} / \mathrm{kg}, \\
\text { p.o. })\end{array}$ & $\begin{array}{c}140.35 \pm \\
4.04 \mathrm{~b}\end{array}$ & $\begin{array}{c}116.52 \pm \\
4.36 \mathrm{~b}\end{array}$ & $\begin{array}{c}55.10 \pm \\
1.98 \mathrm{~b}\end{array}$ & $\begin{array}{c}63.51 \pm \\
5.32 \mathrm{~b}\end{array}$ & $\begin{array}{l}21.19 \pm \\
0.88 \mathrm{~b}\end{array}$ & $\begin{array}{l}6.10 \pm \\
0.16^{b}\end{array}$ & $\begin{array}{c}5.21 \\
0.12 b\end{array}$ & $\begin{array}{l}0.65 \pm \\
0.02 \mathrm{~b}\end{array}$ \\
\hline
\end{tabular}

The results are expressed as mean \pm S.E.M. $(n=6){ }^{\mathrm{a}} \mathrm{p}<0.001,{ }^{\mathrm{b}} \mathrm{p}<0.01$ and $\mathrm{c} p<0.05$ extract / drug treated groups were compared with diabetic control group. $\mathrm{a} p<0.001$ diabetic control group was compared with normal group. One way ANOVA by Tukey's multiple comparison test.

Legends: $\mathrm{TC}=$ Total cholesterol, $\mathrm{TGL}=$ Triglycerides,$\quad \mathrm{TP}=$ Total protein, $\mathrm{CR}=$ Creatinine, $\mathrm{HDL}=\mathrm{High}$ density lipoprotein, $\quad \mathrm{LDL}=\mathrm{Low}$ density lipoprotein, $\mathrm{VLDL}=$ Very low density lipoprotein

Effect of Hiptage benghalensis extract on acute toxicity study

Acute toxicity study revealed the non-toxic nature of the Hiptage benghalensis extract. There was no mortality or any toxic reactions found at the maximum tested dose level of $2000 \mathrm{mg} / \mathrm{kg}$.

Effect of Hiptage benghalensis extract on oral glucose tolerance test: The serum glucose levels of normal rats reached a peak at $60 \mathrm{~min}$ after the oral administration of glucose $(3 \mathrm{~g} / \mathrm{kg}$ ) and gradually decreased to $116.0 \mathrm{mg} / \mathrm{dl} \mathrm{and} 104.2$ $\mathrm{mg} / \mathrm{dl}$ in 2 hours. The pretreatment with Hiptage bengahlensis extract (100 and $200 \mathrm{mg} / \mathrm{kg}$ ) and Glebinclamide (2.5 $\mathrm{mg} / \mathrm{kg}$ ) elicited decreased serum glucose level significantly $(\mathrm{p}<0.001)$ as compared to the control group. 
Effect of Hiptage benghalensis extract on STZ induced rats: On repeated oral administration of the vehicle, Hiptage benghalensis extract or Glebinclamide, for 21 days, a sustained and significant $(\mathrm{p}<0.001)$ decrease in the serum blood glucose of the diabetic rats was observed at a dose of 100 and $200 \mathrm{mg} / \mathrm{kg}$ in a dose dependent manner as compared to the vehicle treated group. Glebinclamide also showed a significant $(p<0.001)$ decrease in serum glucose at a dose of $2.5 \mathrm{mg} / \mathrm{kg}$, p.o. as compared with the vehicle treated group. Normal control animals had an increase in their body weight, but diabetic rats showed significant reduction in body weight during the 21 days treatment. STZ caused body weight reduction, which was reversed significantly $(\mathrm{p}<0.001)$ by extract of Hiptage benghalensis after 21 days of treatment.(Table no.8) Serum triglycerides, creatinine, total cholesterol, LDL, and VLDL cholesterol levels were elevated significantly $(\mathrm{p}<0.001)$ in STZ induced diabetic rats as compared to normal rats (Friedewall, 1972). In STZ induced diabetic rats, when treated with the Hiptage benghalensis extract/ Glebinclamide, there was a significant ( $\mathrm{p}<0.001)$ reduction in the elevated levels of serum triglycerides, creatinine, total cholesterol, LDL, and VLDL cholesterol. Similarly, decreased HDL, albumin, and total protein in serum during STZ induced diabetes were found to be significantly (p < 0.001 ) increased by Hiptage benghalensis extract and Glebinclamide treatment. It involves over-production (excessive hepatic glycogenolysis and gluconeogenesis) and decreased utilization of glucose by the tissues. The results of the present study indicate that Hiptage benghalensis extract (100 and $200 \mathrm{mg} / \mathrm{kg}$ b.w.) was found to reduce the glucose level in glucose loaded animals and in STZ induced diabetic animals. STZ has been shown to induce free radical production and cause tissue injury. The pancreas is especially susceptible to the action of STZ-induced free- radical damage (Hunt, 1990). Induction of diabetes with STZ is associated with a characteristic loss of body weight, which is due to increased muscle wasting and due to loss of tissue proteins. The differences in the body weights observed during the period of treatment of the rats treated with Hiptage benghalensis extract/ Glebinclamide were increased as compared to the diabetic control, which may be due to its protective effect in controlling muscle wasting, i.e., reversal of gluconeogenesis and may also be due to proper glycemic control. In STZ animals, there was an increase in the value of total cholesterol (TCH), triglycerides (TG), LDL, VLDL, except HDL and protein values (albumin and total protein), while the extract treated group showed an increased value of HDL, protein values, and reduced VLDL, TC, and TG in a significant manner. This reduced the VLDL, TC, and TG; it may be presumed that the extract is responsible for the enhancement of the transcription of lipoprotein lipase similar to that of insulin, since in the untreated or under treated diabetes animals, the level of triglycerides and cholesterol increases due to increased production of VLDL and unavailability of protein lipase which hydrolyses the triglycerides to VLDL because of insulin deficiency. Diabetic nephropathy in uncontrolled diabetes is a serious micro-vascular complication leading to glycosylation of renal basement membranes and result in increased creatinine concentrations. While the diabetic controls had significantly higher amounts of creatinine in the serum, the Hiptage benghalensis extract administered diabetic rats exhibited significantly lowered creatinine level. This reduction could be a result of improved renal function due to a reduced blood glucose concentration and subsequent glycosylation of renal basement membranes. Thus, this active principle may be responsible for the observed antidiabetic effect of the Hiptage benghalensis extract. Phytochemical studies of ethanolic extract revealed the presence of flavonoids, steroids, triterpenoids, tannins and ph e n ol i c compounds (Cheng et al., 2007). Any of these above compounds could have induced the observed effects (Odetola et al., 2006). Thus, any of these compouds may be responsible for the observed antidiabetic effect of the Hiptage benghalensis extract. The ethanolic extract of Hiptage benghalensis was found to exhibit an antidiabetic activity in STZ-diabetic rats. Further pharmacological investigations are needed to elucidate the mechanism of the observed antihyperglycemic effect.

CONCLUSION: The stems of the plant were extracted by hot percolation and subjected to antidiabetic activity. The acute oral toxicity studies followed by OECD guidelines - 423, fixed dose procedure, showed that ethanolic extract up to 2000 $\mathrm{mg} / \mathrm{kg}$ are non toxic and safe. On the basis of pharmacological studies $200 \mathrm{mg} / \mathrm{kg}$ of extract of stems of the Hiptage benghalensis exhibited significant antidiabetic activity than the lower dose level with standard drug as Glebinclamide. The antidiabetic activity of the plant has been further confirmed by biochemical parameters and histopathological studies. The phytochemical studies revealed the presence of phenols, tannins, flavonoids, steroids \& triterpenoids. These components may be responsible for the antidiabetic activity. Further studies are needed to characterize the active principle of Hiptage benghalensis which can offer antidiabetic properties and to establish that the whole plant is of utmost importance in serving the mankind's urgent health needs.

\section{References:}

1. Almdal TP and Vilstrup H. Strict insulin treatment normalizes the organic nitrogen contents and the capacity of urea-N synthesis in experimental diabetes in rats. Diabetologica 1988;31:114-8.

2. Ashutosh Kar -Pharmacognosy and Pharmacobiotechnology, p.19-20.

3. Basset J "Vogel's Text Book of Quantitative Inorganic Analysis", 4th edition, ELBS - Longaman, Essex, UK, p.196. (1985). 
4. Book of practical Pharmacognosy”, baillore, London, p.363 (1984).

5. Bonner-Weir S. Morphological evidence of pancreatic polarity of beta cells within islets of langerhans. Diabetes 1988;37:616-21.

6. Casey GR, Joyce M, Nagle, R.G., Chen, G., Hayes, D. Pravastatin modulates early diabetic nephropathy in an experimental model of diabetic renal disease. J Surg Res 123,2004,176-81.

7. Chopra and Nayer PID Hiptage benghalensis (L).Kurz. Syn. H.madablota Gaert. (Glossary Indian medicinal plantsChopra and Nayer PID), New Delhi - 1956. p.134.

8. Cooper and Gunn, In; Tutorial Pharmacy, JB Publishers, New Delhi, p.259.

9. Dash G.K. Indian Journal of Natural Product; 2003, 19-24.

10. Demerdash FM, Yousef MI, Abou El-Naga NI. Biochemical study on the hypoglycemic effects of onion and garlic in alloxan-induced diabetic rats. Food Chem Toxicol 2005;43:57-63.

11. Das Chowdary, A note on the estimation of free amino acids, sugar and organic acids from gummy and resinous plant material. Ind. J. Plant Physiol., 1967, 10: 196-201

12. Friedewall WI, Levy RI, Fredrickson DS. Estimation of the concentration of low density lipoprotein cholesterol in plasma, without use of the preparative ultracentrifuge. Clin Chem 1972;18:499-502.

13. Friedewall WI, Estimation of the concentration of low density lipoprotein cholesterol in plasma, without use of the preparative ultracentrifuge. Clin Chem 1972;18:499-502. 